\title{
Bulgarların Kökeni ve Bağımsızlık Hareketleri ${ }^{1}$ The Origin of The Bulgars and Their Independence Movements
}

\author{
Yunus Emre TANSÜ* \\ Semra ÇERKEZOĞLU**
}

\begin{abstract}
$\ddot{O} \mathbf{z}$
Arkeolojik kalıntılar, Bulgarların, Türk menşeli bir kavim olduğuna işaret etmektedir. Göktürklerin, idaresi altında yaşayan Bulgarlar, Göktürklerin güçsüz döneminde, 630'da “ 'Büyük Bulgarya Devletini" kurmuşlardır. $\mathrm{Bu}$ devlet, Hazar Hakanlı̆̆ı tarafindan parçalanmıştır (665). Asparuh idaresindeki Bulgarlar, Tuna’ya doğru yönelmişler, burada, Oğuzlar ve Hunlarla karışarak Bulgar adı altında, bu topraklarda hakimiyet kurmuşlardır. Büyük Kosova Savaşı'ndan sonra (1389) Tuna ve Vidin'e kadar bütün Bulgaristan Osmanlı hakimiyetine girmiş ve halk, dini ve milli değerlerinde özgür bırakılmıştır. Bulgarların bağımsızlık hareketleri, ilk defa XVIII. yüzyılın ikinci yarısında başlamıştır. 1828/29 Osmanlı-Rus Savaşı'ndan sonra Ruslar, Bulgarların çete faaliyetlerini desteklemiş̧lerdir. Bulgarlar, Rusların Balkanlardaki faaliyetlerinden faydalanarak, Osmanlı Devleti'nden ayrılma eğilimi göstermeye başlamışlardır. Bulgar bağımsızlık hareketi, hem ideolojik gelişme hem de organizasyon olarak 1860'larda doruk noktasına ulaşmıştır. Bulgar Ortodoks Kilisesi 11 Mart 1870 tarihindeki bir fermanla tanınmıș, sonrasında milli Bulgar kilisesi, kurulmuştur. Dini bağımsızlıklarını kazanan Bulgarlar, siyasi bağımsızlıklarını kazanmak için savaşmaya, 1875 ve 1876 yılında yapılan, iki güçlü ihtilal teşebbüsüyle devam etmiştir. 1877-1878 Savaşı Osmanl1- Rus mücadelesinde, Bulgarlar Rusya'ya büyük destek vermiş, Bulgar gönüllüleri, Rus ordusunda Osmanlı Devleti'ne karşı savaşmıştır. Bu savaşta, çok sayıda Müslüman hayatını kaybetmiş ve çok sayıda Müslüman, evlerini bırakarak göç etmek zorunda kalmıştır. $\mathrm{Bu}$ çalışmada; Bulgarların Türk kökenli bir topluluk olduğu, siyasi bağımsızlıklarını elde etme sürecinde Türk kimlikleri ile değil, dini kimliklerine göre faaliyetlerine yön verip, bağımsızlıklarını elde etme mücadeleleri anlatılmışıır.
\end{abstract}

Anahtar Kelimeler: Bulgarlar, Panslavizm, Bağımsızlık, Osmanlı Devleti.

\begin{abstract}
Archaeological remains indicate that the Bulgarians were a Turkish tribe. The Bulgarians living under the rule of the Gokturks established the 'Great Bulgarian State' in 630, during the weak period of the Gokturks. This state was distributed by the Khazar Khanate (665). The Bulgarians under the administration of Asparuh headed towards the Danube, where they joined the Oghuzes and Huns and dominated these lands under the Bulgarian name. After the Great Kosovo war (1839), all Bulgaria up to the Danube and Vidin came under Ottoman rule and was freed to live the religious and national values of the people. Independence movements in the Bulgarians first started in the second half of the 18th century. After the 1828-29 Ottoman-Russian war, the Russians supported the gang activities of the Bulgarians. The Bulgarians started to tend to leave the Ottoman State by taking advantage of the activities of the Russians in the Balkans. The Bulgarian independence movement reached its peak in the 1860s, both as an ideological development and as an organization. The Bulgarian Orthodox Church was known for an edict on March 11, 1870, after which the national Bulgarian church was established. The Bulgarians, who gained their religious independence, continued to fight to gain their political independence, with two strong attempts at revolution in 1875 and 1876. The Battle of 1877-1878 In the Ottoman-Russian struggle, Bulgarians gave great support to Russia, Bulgarian volunteers fought against the Ottoman State in the Russian army. In this war, many Muslims died and many Muslims had to migrate by leaving their homes. In this study; The Bulgarians are a Turkish origin society, not with Turkish identities in the process of achieving their political independence, give directions their activities according to their religious identities, struggles to achieve their independence are described.
\end{abstract}

Keywords: Bulgarians, Panslavism, Independence, Ottoman State.

\section{Giriş}

Bulgarların, Türk menşeli bir kavim oldukları artık genel kabul gören bir gerçektir. Bunun en açık kanıtı, arkeolojik kalıntılar, Proto-Bulgar dil kalıntıları ve İdil Bulgarları'na ait mezar taşlarındaki kitabelerdir. Bulgarların çok eskiden nerede yaşadıkları hangi Türk kavmine mensup oldukları ve tarih sahnesine çıktıkları Azak Denizi çevresine ne zaman

\footnotetext{
${ }^{1}$ Bu makale, Doç. Dr. Yunus Emre Tansü danışmanlığında, Semra Çerkezoğlu tarafindan hazırlanan, H. 1291 Vilâyet-i Tuna Sâlnâmesi'nin Transkripsiyonu ve Değerlendirilmesi adlı Yüksek Lisans tezinden uyarlanmıştır. * Doç. Dr. Gaziantep Üniversitesi, Fen Edebiyat Fakültesi, Tarih Bölümü, ytansü@gmail.com

** Gaziantep Üniversitesi, Sosyal Bilimler Enstitüsü, Tarih Bölümü, semracc27@gmail.com
}

Tansü, Y. E., \& Çerkezoğlu, S. (2020). Bulgarların Kökeni ve Bağımsızlık Hareketleri, Asia Minor Studies, Cilt 8 Say1 2, 490-500, Gönderim tarihi: 09-03-2020, Kabul tarihi: 14-05-2020.

Araştırma Makalesi. 
geldikleri ise kesin olarak tespit edilememektedir. Bulgarlar hakkında en eski yazılı kayıt, M.S. III. yüzyılda yaşadığı anlaşılan Suriyeli Mar- Abas- Katinu'ya aittir. Buna göre: Bulgarlar M.Ö. 149-127 yıllarında, Kafkasların kuzeyinde yaşıyorlardı. Bu kayıt, VIII. yüzyıl Ermeni tarihçisi Moisey Khoren'li tarafından da aktarılmıştır. Başka herhangi bir kaynakta, mesela Bizans Kroniklerinde bunu teyit edecek kayıtlara rastlanmamaktadır (Kurat, 2002: 108).

V. yüzyıl son çeyreğine kadar kaynaklarda, “Bulgar” diye bir kelimeye rastlanmamıştır. Kaynaklarda bu kelimeye ilk defa, Bizans imparatoru Zenon (474-491)'un Doğu Gotlarına karşı, askeri deste sağlamak için 482'de yardımlarına başvurduğu Karadeniz kuzey- batı kıyılarında oturan bir topluluğu göstermek üzere ortaya çıkmıştır. "Bulgar', kelimesinin, Türkçeden başka hiçbir dilde açıklaması yapılmamıştır. Türkçede manası ise; karışmak, karıştırılmak, karışmış olmaktadır (Kafesoğlu, 1983: 92). Bulgar Türklerinin, Karadeniz'in kuzeyinden gelerek ilk Bulgar Devleti'ni kurmalarından (680-681) bugüne kadar, Türk tarihinin araştırılmağa değer en önemi sayfalarından birini, Bulgaristan tarihi teşkil etmektedir (İnalcık, 1943:V).

Göktürk Devleti'nin idaresi altında yaşayan Bulgarlar, 630'da Göktürk Devleti'nin duraklaması "Büyük Bulgarya Devletini" kurmuşlardır. Bu Devlet, 665'den sonra Hazar Hakanlığı tarafından parçalanmıştı. Asparuh idaresindeki Bulgarlar, Tuna'ya doğru ilerleyerek, Balkanlar'a girmiş (668 veya 671), Balkanlarda, Tuna Bulgarları Devleti'ni kurmuştur (Merçil, 2006:13). Burada, Oğuzlar ve kalan Hunlarla karışarak Bulgar adı altında, bu sahada hakimiyet kurmuşlardır. Burada, zaman zaman İstanbul önlerine kadar ilerlemişlerdir (Karal, t.y.: 83).

Bulgarların ve Avarların, Bizans'la mücadeleleri sırasında, dağınık Slav topluluklarının, Balkanlara yerleşmesini sağlamış ve böylece Balkan Yarımadası özelikle V. yüzyıl sonlarından itibaren güçlü bir şekilde Slavlaşmaya başlamıştır. Karadeniz'in kuzeyinde, Büyük Bulgarya Hanlığı'nın dağılmasından sonra Bulgarlardan bir kısmı batıya ilerleyerek (645) Balkanlarda Bizans'la yüzyıllardır süren mücadelelerini devam ettirmişler ve 680-681 tarihlerinde, yerleşmiş Slav kabileleri üzerinde, yepyeni bir devlet kurmuşlardır. İşte bugünkü Slav Bulgarlar, tarihlerini bu devletle başlatmışlardır.

Bulgar Türkleri yüksek bir kültüre sahibi idiler. Geldikleri yerde sürücülük kadar ziraatla da uğraşmaktadırlar ve şehirleri vardır. Onlardan kalan muazzam abideler, kendilerinin hususi bir yazıları, takvimleri ve Bizans'ın mimarilerinden ayrı olup, hususî karakterde bir mimarileri olduğunu ortaya koymuştur. VIII. yüzyılda Slavların Bulgar aristokrasisi arasına kabul olunması, bu Türk devletinin Slavlaşmasına doğru büyük bir adım oldu. Omurtak Han'dan (816-831) Slavlașma dahada hızlanmıștır. 65 yılında Hrıstiyanlığın kabulü ile beraber Türk Bulgarlar asimile olmuştur. Resmi dil Slavlaşmış, Türkçe unvanlar atılmıştır. Bulgarlar Bizans'la yaptığı uzun bir mücadele sonunda Bizans hakimiyetini tanımaya da mecbur olmuştur (1018- 1185) (İnalc1k, 1943: V-VI).

Bulgaristan üzerinde, artan Hrıstiyanlık baskısı Bulgar Türklerinin hızlı bir şekilde Bizans kültürünün etkisi altına sokmuştur (Kurat, 1993: 798). Bulgarların, Bizans hakimiyeti tesirinde olduğu sıralar, Karadeniz kuzeyinde bir çok Türk kavimleri “Peçenekler, Oğuzlar, Kumanlar'" Balkanlara gelip yerleşmişlerdir. Bunlardan Kumanlar müstakil bir Bulgar Devletinin yeniden kurulmasına ön ayak olmuştur. Bundan sonra Bulgar Devleti bir süre Altın Ordu Kıpçakların himayesinde yaşamıştır. XIII. yüzyılda Balkanlara Anadolu Türklerinin, akınları başlamıştır. Yüzyılın ortalarında Osmanlı Türkleri yarımadaya güçlü bir şekilde yerleşmiştir. Büyük Kosova savaşından sonra (1839), Tuna ve Vidin'e sınırlarına kadar, tüm Bulgaristan toprakları, Osmanlı hakimiyetine girmiştir. Bulgaristan üzerinde Osmanlı Devleti'nin hakimiyeti, beş yüz yıl sürecektir (İnalcık, 1943: VI). 


\section{Osmanlı İdaresinde Bulgaristan}

Osmanlı Devleti, Bizans'taki bir taht mücadelelerini yararına kullanarak, 1344 y1lında ilk defa olarak Balkanlar'a ayak basmıştır. Bu sırada, Balkan coğrafyasında farklı mezheplerden, milletler çıkmıştır. Balkanlar'ın kuzeydoğusunu; aslen Türk olup sonradan Slavlaşan Bulgarlar, teşkil etmektedir.

Osmanlı Devleti'nin, Rumeli’ye geçtiği sıralarda Bulgar Çarlığında İvan Alexsandr Asen tahttaydı, kendisi Osmanlılara karşı güçlü bir direniş göstermiş ancak 1365 yılında, hayatını kaybetmiştir. Ölümün ardından, taht kavgaları ile devlet zayıflamış, bu durum Bulgaristan'daki Osmanlı hakimiyetini kolaylaştırmıştır. Yıldırım Beyazıd'ın oğlu Süleyman Çelebi kumandasındaki Osmanlı ordusu, Tırnova'yı ele geçirerek (1393), Bulgar Krallığına son vermiştir (Uzunçarşıl1, 1987: 161). Bulgaristan, Rumeli Beylerbeyliği'ne bağlanmıştır. 24 sancağa ayrılan Rumeli Beylerbeyliğinin merkezi Sofya olmuştur. Sofya, Vidin, Niğbolu, Silistre, Köstendil ve Çirmen eski Bulgaristan sınırlarını teşkil eder (Şentürk, 1992: 5). Osmanlı Devleti, 1878'e kadar süren 500 yıllık "Bulgar Tarihi”, içerisine girmiştir (Kurat, 1993: 799).

Bulgaristan'da halkın, dini ve milli değerlerine saygı gösterilmiş, dini ne olursa olsun, hoşgörü politikası uygulanmıştır (İnalcık, 1993: 292). Hoşgörülü bir yönetimle, karşılaşan halk da Osmanlı Devletine karşı yakınlık göstermiştir (Şentürk, 1992: 5). Osmanlı Devleti, Balkanlar' da feodal anarşiye son vermiş, köylüyü ezen boyarları kaldırmış, keyfi haksızlıklara meydan vermeyen, sağlam bir toplumsal nizam kurmuştur (İnalcık, 1943: VI). Yabanc1 tarihçilerin, dahi kabul ettiği bir gerçek; o dönemde, Bulgar köylüsünün Rus köylüsünden ve Avrupa'nın bir çok köylüsünden, refah düzeyi yüksek hür bir yaşam sürmektedir.

Osmanlı, Tanzimatın ilanından sonra, Bulgar köylüsünün toprak sahibi olması zorunluluğunu, fark ettiği sırada Bulgarlarda milliyetçilik hareketleri başlamıştır (Karal, t.y.: 84).

\section{Tanzimat-ı Hayriye ve Bulgar Meselesi}

XIX. yüzyılda, Osmanlı Devleti’nin, muazzam devlet kadrosu yerini dağılmaya bırakır. Balkanlar'da beş milyon nüfus resmen muhtar idarelerle devletten ayrılmış bulunmaktadır. Hrıstiyan halkta, memnuyetsizlik ve başkaldırmalar kendini göstermeye başlar.

Tanzimat Fermanı ile; sarsilan bu muazzam idari yapının ve devlet kadrosunun, yeniden yapılanması hedeflenir (İnalcık, 1943: 1-2). Osmanlı Devleti'nin modernleşme sürecinde bir dönüm noktası teşkil eden, bu ferman, Gülhane Hatt-1 Hümayunu olarak da bilinir. Dönemin Dışişleri Bakanı Büyük Mustafa Reşid Paşa tarafından hazırlanmış ve 3 Kasım 1839 tarihinde Sultan Abdülmecid adına ilan edilmiştir. (Çelik, 2010: 19).

Tanzimat Fermanı, resmi gazete Takvîm-i Vekâyi'de yayınlanarak yürürlüğe girmiştir. Bütün eyalet valisi ve sancak mütesellimine, ayrı ayrı bir ferman ile tebliğ olunmuştur. Gülhane Hatt1-1 Hümayûn'u, büyük bir törenle önce, Sancak merkezlerinde, halkın ileri gelenleri ile beraber, şehrin büyük meydanında halk önünde okunmuştur. ve sonra kazalara ve kasabalar birer birer gönderilip halka izah edilerek, bildirilmiştir (İnalcık, 1964: 642).

Tanzimat Fermanı'nın belli başlı önemli vaatleri şunlardır; Padişahın, bütün halka eşit davranarak, halkın canını, namusunu ve malını güvence altına alması, İltizam sisteminin yerine, yeni bir vergilendirme sistemi getirilmesi, askere almada düzenlemelerdir (Çelik, 2010: 20). Tanzimat Fermanı'nın asıl amacı, Hrıstiyan halkı Devlet'e bağlamak, hukuk prensibine dayanarak, Devlet'in varlığını koruyup sağlamlaştırmak olmuştur (İnalcık, 1943: 3). Fermanda ki maddelerin uygulanmasında bir takım güçlüklerle karşılaşılmıştır. O zamana 
kadar vergi ödemeyen imtiyazlı sınıflar, reforma karşı koymuşlardır. Örneğin; Niș kalesindeki Müslüman halk, daha önceleri vergi ödemekten muâf iken, yeni uygulamalarla beraber, vergiye tabi tutulmayı bir haksızlık saymışlardır (İnalcık, 1964: 642). Ayrıcalıklı Müslüm ve gayrimüslüm gruplar, toprak ağaları ve çorbacı veya kocabaşı, denilen Hrıstiyan liderler imtiyazlarını kaybetme ve yüksek vergiler ödeme taraftarı değildir. Bu gruplar, şarap ve rakıya konulan yüksek vergilerden şikayetçi olmuşlardır. Daha sonra köylüyü, bağlarında iş vermemek ve onların yetiştirdiği üzümü satın almamakla tehdit etmişlerdir. Dini cemaatların liderleri, Osmanlı yönetiminde karşı gerçekleşen milliyetçi hareketlere şiddetle karş1 çıkmışlardı çünkü kendi cemaat üyeleri üzerindeki otoriteleri merkezi yönetim tarafından sağlanmaktadır.

Osmanlı Devleti'ndeki millet sistemi bütün Müslüm ve gayrimüslüm cemaatlere din, eğitim, evlilik, boşanma, ve miras gibi konularda kendi kendini düzenleme yetkisi vermektedir. Fakat Tanzimat'1n, "millet" sistemini demokratileştirmeye yönelik teşebbüs ettiği reformlar sonucu bu dinî liderler, otoritelerini kaybetmeye başlamışlardır. $\mathrm{Bu}$ durumda onlarda milli hareketleri ve ayaklanmaları desteklemeye başlamış, hatta kendi cemaatlarini Osmanlı yönetimine karşı isyana teşvik eder olmuşlardır. Tanzimat reformları, gayrimüslüm tebaaya verilen haklar nedeniyle Müslümanları hayal kırıklığına uğratmıştı. Bazı yüksek rütbeli dini memurlar, ulema, ayanlar ve hatta otoritesini ve ayrıcalıklarını kaybetmiş valiler, Müslüman halkı reformlara karşı kışkırtmışlardır. Bu durum reformlardan büyük beklentilere kapılan gayrimüslüm azınlıklar arasında hoşnutsuzluğa ve milliyetçiliğin yükselmesine neden olmuştur (Çelik, 2010: 20-21).

\section{Bulgarların Bağımsızlık Faaliyetleri}

Bulgarlar, XVIII. yüzyıla kadar, Osmanlı Devleti’ne karşı, kayda değer bir isyanda bulunmamışlardır. Tarihi kayıtlarda; XIII. yy ortalarında, Balkanları dolaşan âlim ve seyyahlar, Tuna nehri ile Ege denizi arasında Türklerden ve Rumlardan bahsederken, bu kaynaklarda "Bulgarlar" diye ayrı bir topluluktan bahsedilmemiştir (İnalcık, 1943: 17). Bulgarlarda, siyasi bağımsızlık hareketleri ilk defa XVIII. yüzyılın ikinci yarısında göründüysede, bu konuda asıl dönüm noktası 1828/29 Osmanl1-Rus savaşında Rusların Edirne'ye kadar gelmesiyle gerçekleşmiştir.

Bulgarlar, Ruslar için Panislavizm politikasının en önemli vasıtası niteliğindedir. Ruslar, Bulgarların çete faaliyetlerine destek vermiş, Panslavist fikirlerine hizmet edecek gençler yetiştirmek amacı ile modern Bulgar okulları açılması desteklenmiştir. Bulgar isyanlarını teşvik ve idare edenler, bu okullardan yetişen ve daha sonra eğitim için Avrupa ülkelerine giden gençlerdir. Bulgarların dinî, sosyal ve kültürel yapıları gereği, kültür olarak kendilerine yakın gören Ruslar, Bulgarlarla ilişkilerini sıcak tutmuş ve geliştirmiştir. Osmanlıları Balkanlardan atabilmek ve sıcak denizlere inebilmek için Bulgarlar önemli bir vasıta niteliğindedir. (Köse, 2006: 240-241).

XIX. yüzyılda, Bulgarlar'ın bağımsızlık hareketlerinin nedenleri arasında; Osmanlı idaresinin bozulması, Fener Patrikhanesinin soygunculuğu ve Rumlaştırma yolundaki çalışmaları, Sırbistan'ın ve Rusya'nın tahrikleri yer alır. Fener patrikhanesi de çalışmalarıyla, Bulgarların bağımsızlık hareketlerine vesile olmuştur (Karal, t.y.: 85).

Rusların, Bulgarların bağımsızlık hareketini desteklemeleri 1829'da daha da şekillenmiştir. Çarı I. Nikola, Macar papazı olan Venelin'i, Bulgar tarihi yazması için görevlendirmiştir. Venelin, 'Mazide ve Bugunkü Bulgarlar' başlıklı kitabı yazdı. Venelin, Bulgarların Slav kökenli olduğunu savunarak, Atilla ve Hunların, eski Bulgarların Volga Slavları olduğunu iddia etmiştir. Fakat Venelin 1839 yılında Moskova'da öldüğü için Bulgarlar üzerindeki çalışmaları yarım kalmıştır (Toprak, 2013: 133). 
Osmanlı Devletinin, Rum patriğine tanıdığı geniş dinî idari imtiyazlar, Rumların Devlet içinde imtiyazlı durumu, kültür seviyelerinin yüksek olması ve Bulgaristan ticaretini ellerine geçirmiş bulunmaları, Rumlaştırma işinde kendilerine büyük kolaylık sağlamıştır. Bulgaristan'da 1800 tarihlerinde metropolitlere gönderdiği bir tâmim ile Bulgar kilise okullarının kapatılmasını kiliselerde yalnız Rumca yazılmış din kitaplarının okunmasını keza okullarda münhasıran Rumca yazılmış din kitaplarının tedrisini emretmektedir. Eski Bulgar edebiyatının kalıntıları her yerde dini bir gayretle yok edilmektedir. Bulgar dili ile âyin yapmak vaazda bulunmak artık yasaktır (İnalcık, 1943: 19-20). Böylece Bulgarlar1 Rumlaştıran ruhban sınıfı, Bulgar dili ve kültürel geleneklerini baskı altında tutmak ve Osmanlı dönemi boyunca Bulgarları karakterize eden tarihsel bir hafıza kaybına yol açmakla suçlanmıştır. Bu durum Bulgarlar arasında Yunan karşıtı duyguların yükselmesine neden olmuştur. Aynı zamanda Yunan burjuvazisi, din ve kültürdeki Yunan hegemonyasına ek olarak köylerde ve dağlık kasabalarda yaşayan Bulgarların ticari aktivitelerini kontrol etmektedir. XIX. yüzyıl boyunca kademeli ortaya çıkan Bulgar burjuvazisi, Rumlaşma hatta onun içine karışma eğilimindedir. Bundan dolayı Bulgar bağımsızlık hareketi, ilk olarak Yunan hegemonyasına karşı bir reaksiyon olarak ortaya çıkmıştır. Patrikhanenin Rumlaştırma politikasına maruz kalan tek millet Bulgarlar değildir. Bulgarlar başta olmak üzere diğer bütün Ortodokslar bu durumdan etkilenmiş, dillerini ve kültürlerini baskı altına alan milliyetçi politikalara karşı mücadele etmişlerdir.

Diğer taraftan 1856 yılında ilan edilen fermanla Ortodoks kiliseside reformlarından nasibini almış ve bu kilisenin de yetkileri sınırlandırılmıştır. Bulgarlar başta olmak üzere her Balkan milli kiliselerini kurmak istemektedir. Bu durumda Rum patrikhanesi'nin otoritesi Balkanlar'da azalmış, Rus imparatorluğu Panislavist ideolojisiyle Balkanlar'da daha etkin olmaya başlamıştır. Tanzimat reformları sayesinde Balkanlardaki Müslüman ve Hrıstiyan okullarının sayısı artmıştır. Bunlardan bazıları Osmanlı yönetimi tarafından açılmasına karşın büyük bir kısmı da özellikle Bulgarların ve diğer azınlıkların açtığı okullardır. Aynı zamanda Amerikalı misyonerler de yeni okullar açarak ve Bulgar dilinde kitaplar dağıtarak eğitime katkıda bulunmaktadır. Bu bakımdan yeni açılan okulların, Rusya'nın siyasi ve kültürel etkisinin ve bir ölçüde Amerikalı misyonerlerin kolejlerinin hep beraber Bulgarlar arasında liberal-milli siyasî ideolojinin gelişmesine katkıda bulunduğunu söylenebilmektedir. Bu arada Rusya; Sofya, Filibe, Rusçuk ve Varna gibi merkezi yerlerde konsolosluklar açmış ve buralara insanları Osmanlı yönetimine karşı organize edecek Panslavist konsoloslar atamıştı (Çelik, 2010: 22-24).

\section{Yüzyıl Bulgar İsyanları}

Bulgarlar, Rusların Balkanlara girmesinden, güç alarak, Osmanlı Devleti’nden ayrılma hareketleri başlatır. 1810'da, Bulgar eşkiyalarının, çoğu dağlardan inerek Rus Ordusuna sığınmışlardır. Bulgarlar, 1821 'de Eflak ve Mora isyanlarından etkilenip, bir hareket düzenlemişler, fakat hareketi hazırlayanlar vaktinde ele geçirilmiştir. 1835'de Velço adında Tırnova'lı bir Bulgar, Mamarçef ile birlikte milliyetçilik tabanlı bir isyan hazırlanmış fakat Türk idaresi harekete geçerek, isyanı bastırmıştır.

$1841^{\prime}$ de Leskofça ve Niş şehir, kasaba ve köyleri hep birden isyan ettiler isyan sebebi vergilerin ağırlığı ve memurların Bulgarlara kötü davranmalarıdır (Karal, t.y.: 89). Asiler, Kontince boğazını, ele geçirmiş ve Müslüman ahaliyi katletmeğe başlamışlardır. Başlarında Mahut Milyo olup, isyan geniş bir sahaya yayılmıştır. Bu arada Vidin havalisinde Sahra (Bulgarların Kula'sı) nahiyeside isyana katılmıştır (İnalcık, 1964: 643). 1849 da Vidin isyanları başlamış ve fasılalarla iki yıl sürmüştür. Bab-1 Âli bu isyanı da güçlükle bastırabilmiştir (Karal, t.y.: 89). 1850 yılında, Vidin, Sahra, Belgradcık ve Lom kazalarında on bin Bulgar köylüsü ayaklanmış, önemli kalelerle sığınmış bulunan Müslümanları 
kuşatmışlardır. Vidin - İstanbul yolunu kesmişlerdir. Her tarafa tahrikçiler salarak isyanı bütün Bulgaristan'a yaymaya çalışmışlardır (İnalcık, 1964: 644).

XVIII. yüzyılın sonlarından itibaren Bulgar coğrafyasında yoğun faaliyetlerde bulunan Rusya, 1841 yılında Niş’te çıkan olaylardan yararlanarak, Babâli’ye Niş halkının Türk yönetiminde memnun olmadığını ve yapılanları yerinde görmek için bir memur görevlendirmek istediğini bildirmiştir. Osmanlı Devleti önce bu isteğin asilleri cesaretlendireceğini düşünse de Rusya'nın bu isteğini kabul etmek zorunda kalmıştır. (Uzun, 2002: 45).

Tazminat Fermanı'nda, Osmanlı halkının, haklar yönünden eşit olduğu belirtilmiş, bu durum İstanbul'daki Bulgarların bir "papaz evi" açmak isteklerini, Devlet'e bildirmek için vesile hazırlanmıştır. Bulgarların bu isteği Tanzimat hükümlerine uygundur, fakat mevzuat hükümlerine aykırıdır, Çünkü İstanbul'da fetihden beri kilise yapılması şer'an menedilmiştir. Hatta Rum, Ermeni ve Yahudi mâbetlerinin tamiri için bile ilgililerin divana resmen başvurarak hüküm ve ferman almaları usuldendir. Bab-1 Âli bu durumu göz önünde bulundurarak, Bulgarların bir kilise değil fakat Fener'de bir papaz evi yapmalarına müsaade etmiştir. Bu suretle İstanbul'da, Bulgarların Rum kilisesinden ayrılmaları hareketi fiîli bir değer kazanmıştır (Karal, t.y.: 90-91).

Vidin, Niş ve Tırnova gibi önemli yerlerde Bulgar ayaklanmaları sonrası Bulgar bağımsızlık hareketi hem ideolojik gelişme hemde organizasyon olarak 1860'larda doruk noktasına ulaşmıştır. 1862'de merkezi Bükreş’te olan Bulgar İhtilal komitesi kurulmuştur (Şentürk, 1992: 182). Osmanlı Devlet adamları taşra yönetiminde reformun kaçınılmaz olduğunu fark etmiş ve 1863 yılı sonlarında, Keçecizade Fuad Paşa'nın nezaretinde Mithad Paşa ve Ahmed Cevdet Paşa'nın da katıldıkları bir komisyon teşkil edilmiştir (Gençoğlu, 2011: 34). Ali ve Fuat Paşa'ların amacı, Mithad Paşa'nın Niş eyaletindeki uygulamalarını esas alarak yeni bir vilayet idaresi ortaya koymuştur (Kılıç, 2005: 101). Komisyonun çalışmaları sonucunda, Tuna Vilayetine özel bir nizamname düzenlenerek, 8 Kasım 1864'te resmi gazetede yayınlanarak yürürlüğe sokulmuştur. (Şentürk, 1992: 253-271). Tuna Vilayeti Nizamnamesi aslında devletin tamamına uygulanmak amacıyla hazırlanmış, Tuna vilayeti, bu nizamnamenin ön uygulama alanı olmuştur. Niş, Vidin ve Silistire eyaletleri birleştirilerek Tuna Vilayeti kurulmuştur. Yeni teşkil edilmiş vilayetin başına da Niş Valisi Mithad getirilmiştir. Nizamname, büyük ölçüde Fransa taşra yönetim sisteminden yaralanılarak hazırlanmıştır (Şentürk, 1992: 168-181).

Tuna vilâyetindeki dört yıllık valiliği boyunca Mithad Paşa ayrılıkçı hareketlere ve ve Rusya'nın Panslavist politikalarına karşı başarılı bir şekilde mücadele göstermiştir. Bunda başka "Osmanlıcılık" ideolojisi altında, gayrimüslüm nüfusu ve Müslümanlarla birleştirmeye yönelik birçok reformlar gerçekleştirmiştir. Bu arada İstanbul' da bulunan Rus büyükelçi Kont N. P. İgnatiev, Mithad Paşa'nın politikalarının direkt olarak Rus Paslavist politikalarını hedef almasında korkarak Tuna vilâyetinden geri çağrılmasını için mücadeleler vermiş ve padişaha baskı yapmıştır (Çelik, 2010: 24).

Bulgaristan sınırları dışında hazırlanan, Bulgar Ihtilali, 1867'de patlak vermiştir. Bükreş, İbrail, Kalas, Yerköyü, Eflak'da, Rusya'nın etkisi altında bulunan Beserabya'da Bulgar komitelerini teşkilatlandıran sevk ve idare eden merkezler vardır. Bu çeteler 1867'de Tuna'yı geçerek, Ziştovi yakınlarında Bulgarları genel bir isyan hareketine teşvik etmeye başlamışlardır. Bunlar yağma ve katliam yapmamakta, Hrıstiyan ve İslam halkı zulümden ve katliamlardan kurtarmak ve iyi bir idareye nail etmek için silaha sarıldıklarını iddia etmektedirler. Halka dağıttıkları beyannâmerlerde 'Balkan Muvakkat Hükûmeti' tabiri bulunduğu gibi bu beyannâmeye ekli birde Bulgar milli marşı mevcuttur. 
Tuna valisi Mehmet Sadri Paşa, asileri durdurmakta gerekli hızı gösteremediği için Mithad Paşa olağanüstü bir memuriyetle Bulgaristan'a gönderilmiş, Mithad Paşa kısa sürede isyanları bastırmıştır. Ele geçirilen suçlular Rusçuk'ta ve Tırnova'da mahkeme sonucu, idam edilmişlerdir. Mithad Paşa, hükûmete verdiği raporda, Bulgaristan'da gelişmiş bulunan milliyetçilik propagandası üzerinde durarak devletçe, askerlik ve eğitim alanlarında alınması gerekli tedbirleri göstermiştir. Fakat bunlar gerektiği gibi idrak edilmediği için Bulgaristan meselesi, mesele olarak kalmaya devam etmiştir (Karal, t.y.:93).

1868 yılında Mithad Paşanın görevinden alınmasından sonra Bulgarların siyasi organizasyonları tekrar güç kazanmış ve Bulgarların, Osmanlı yönetimine ve Rum Patrikhanesi'ne karşı mücadelesi hızlanmıştır. Bu organizasyonların 1868 yılından sonraki en büyük başarılarından biriside Bulgar Ortodoks Kilisesinin 11 Mart 1870 tarihindeki bir fermanla tanınması olmuştur (Şentürk, 1992: 220-221). Bu suretle müstakil ve milli Bulgar kilisesi kurulmuştur. $\mathrm{Bu}$ kuruluş ile Bulgarlar Rum patrikhanesinin nüfuzundan ve Rum papazlarının istismarından kurtulmuşlardır (Karal, t.y.:93). Bulgar Milli Kilisesi, Bulgar cemaatinin dinî işleriyle bağımsız olarak ilgilenecektir (Şentürk, 1992: 221). Bulgarlar bağımsız bir devlet kurmak ve milli bir kiliseye kavuşmak için Fener Patrikhanesiyle mücadele ederken, diğer taraftan da Osmanlı hakimiyetini sarsmaya devam etmişlerdir. (Karal, t.y.: 93).

Dini bağımsızlıklarını kazanan Bulgarlar, siyasi bağımsızlıklarını kazanmak için savaşmaya, 1875 ve 1876 yılında yapılan iki güçlü ihtilal teşebbüsüyle devam etmiştir. Osmanlı yönetimine karşı gerçekleşen bu ayaklanmalar, 1875 yılındaki Bosna-Hersek ayaklanmasının bir devamı olarak düşünülmektedir. Bu Balkanlar'da Osmanlı Devletinin feci yenilgisiyle sonuçlanan 1877-1878 Osmanlı - Rus savaşıyla sonuçlanan bir dönüm noktasıdır. (Aydın, 2005:146). 1875 Bulgar ayaklanmasının başarısızlığı üzerine Bükreş’te kurulan İhtilal Komitesi fiilen çözülmüş ve çoğu üyasi silahlı ayaklanma fikrinden uzaklaşmıştır. Fakat Panslavstlerin de etkisiyle genç bir grup, silahlı ayaklanma fikrini desteklemeye devam etmiştir. $\mathrm{Bu}$ gruba göre milletler arası durum ayaklanma için elverişlidir. Aylar boyu devam eden Bosna - Hersek ayaklanması uluslar arası bir sorun haline gelmiştir. Bosna - Hersek'in durumu için toplanacak bir konferansta büyük bir ayaklanmayla Avrupalı Devletlerin dikkatini çekebilmektedir. Böylece büyük Devletlerin olaya müdahale etmesi sağlanabilmektedir (Şimşir, 1989: LXXXVII).

1876 ayaklanmasının başarısızlığa uğramasına rağmen Avrupa'da yarattığı etki ve Bab-1 Âli'nin güçsüzlüğü Avrupalı büyük Devleterin atağa geçmesine neden olmuştur. Temmuz 1876 tarihinde, Osmanlı Devleti'nin paylaşılmasını tasarlayan Rusya ve Avusturya 2 Aralık'ta başlayacak olan Avrupa Konferansı'nın İstanbul'da toplanmasını önermiştir. Asıl amaç Osmanlı Devleti'nin reformlar yapmasını sağlamaktır. Aksi halde çıkacak yeni isyanlar Osmanlı Devletini parçalayacaktır. (Toprak, 2013: 140). Konferans devam ederken Mithad Paşa sadrazam olarak atanmış ve atandıktan sonra dört gün sonra onun gayreti sonucu ilk Osmanlı anayasası 23 Aralık 1876 tarihinde ilan edilmiştir (Çelik, 2010: 25).

Kanûn-i Esasi Sırbıstan- Karadağ Savaşının sonunu getirmek ve Balkanlardaki sorunları görüşmek üzere toplanan İstanbul Konferansı'nın başlangıcı öncesi ilan edilmiştir. Meşrutiyetin ilanı Avrupa'da olumlu etkiler yapmıştır. Mithad Paşa, İstanbul konferansı delegelerinin, Devletin içişlerine karışıcı, bağımsızlıkla bağdaşmaz ve kabul edilemez nitelikteki karar ve önerilerinin reddedilmesinde etkin bir rol almıştır (Özgüldür ve Özgüldür, 1994: 319). Avrupa güçleri Osmanlı Devleti'nin konferansta alınan kararları içeren bir ültimataom vermiştir. Buna göre Bosna ve Hersek ayrılacak ve bunlara otonomi verilecek ve bu bölgeler, kendi askerî gücüne sahip olacaktır. Bulgaristan, doğu ve batı olarak ikiye bölünürek otonomi kazanacak ve Hrıstiyan valiler tarafından yönetilecektir. Ayrıca direkt 
olarak Bulgaristan'daki reformları ve yeni idareyi denetlemek üzere Avrupa güçlerinin temsilcilerinden oluşan bir komisyon Bulgaristan'da kurulacaktır. Ve 500 Belçikalı asker, bu komisyonu korumakla görevlendirilecektir. Bundan başka Osmanlı Devleti sınırları genişletecek olan Sırbıstan ve Karadağ'dan askerî gücünü çekmek zorunda kalacaktır (Armaoğlu, 2003: 513). Osmanlı hükümeti tarafından bu kesin uyarıya verilecek yanıt, Mithad Paşa tarafından belirlenmiş ve parlemontaya sunulmuştur. Mithad Paşa konferansta alınan kararları kabul etme taraftarı değildir. Mecliste yaptığı meşhur konuşmasında ültimatomun ayrıntılarını anlatmış ve taleplerin, Osmanlı Yönetimi için kabul edilemez olduğuna işaret etmiştir. Avrupa güçlerinin temsilcileri manalı bir şekilde İstanbul'u terk etmiştir. Daha sonra Londra' da yeni bir konferans organize ettilerse de 1877-1878 Osmanl1Rus Savaşı'na neden olacak sorunlar çözülememiştir (Çelik, 2010: 26).

1877-1878 Osmanlı - Rus Savașı esnasında, Bulgar gönüllü askerleri, Rus ordusunda Osmanlı Devleti'ne karşı savaşmıştır. Bu savaşta çok sayıda Müslüman öldürülmüş, kalanlar ise göç etmek zorunda kalmıştır. Boşalan bölgelere, Bulgarlar iskan edilmiştir. Bu topraklar, Bulgar vatanı ilan edilmiştir. Bulgaristan'ın doğusundaki köyler, önce karma olmuş, sonra da tamamen Bulgarlaşmıştır. Özellikle Tuna'nın gerisinde yaşayan "Bulgar Gönüllüler Birliği'” nin çekirdeğini oluşturacak şekilde örgütlenmiştir (Tuğlacı, 1984: 92). Müslümanların boşalttıkları yerlere Bulgarlar yerleştirilmiştir ve bu toprakların Bulgar vatanı olduğu iddia edilmiştir. Bu tip göç hareketlerine daha çok Elana, Rozgrad, Kotel ve Dobruca bölgesinde rastlanmaktadır. Göç hareketleriyle Bulgaristan'ın doğusundaki köyler, zamanla tamamen Bulgarlaşmıştır. Şehirdeki Bulgarlaşma oranı köylerden daha da fazladır. Örneğin, 1871 yılında Sofya'daki şehir nüfusunun \%26'sı Türk iken, bu oran 1880 yılında \% 2,6'dır. Şumnu'da 1865 yılında \% 52 olan Türk nüfus oran1, 1880 yılında \% 42'ye, Tatarpazarcığı'nda 1868 yılında \%28 olan oran 1884 yılında \%16'ya, Köstendil'de 1878 y1lında \% 56 olan oran 1880 yılında \% 16'ya düşmüştür (Toprak, 2013: 143). Bu savaş sonunda Osmanlılar Devleti, topraklarının üçte birini ve nüfusunun yüzde yirminin üzerindeki kısmını kaybetmiştir.

\section{Tuna Vilayetinde Nüfus, Etnik ve Dini Yapı}

Osmanlılar, ilk fetihlerinden başlayarak Balkanlar'da düzenli iskan siyaseti sürdürmek istediler. XIV. yüzyılın ikinci yarısından itibaren toplu Türk göçleri ve yarımadaya yerleşim başlamıştır. Moğollar, XIII. yüzyılda Anadolu'ya hükmettiklerinde doğudan Batı Anadolu'ya büyük bir göç dalgası gerçekleşmiştir. Devamında, XV. yüzyılın başında Timur'un istilasının neticesinde çok sayıda insan Osmanlı Balkanları'na giriş yapmıştır. Bu göç hareketinin sonucunda Trakya, Doğu Bulgaristan, Maritsa Nehri vadisi ve Dobruca bölgesi, Türk nüfusunun yoğun olduğu bir bölge haline gelmiştir. Osmanlı nüfus ve vergi sicilleri, XVI. yüzyılda Müslüman Türklerin bu bölgelerde nüfusun büyük bir parçasını oluşturduğunu belirtmektedir (Çelik, 2010: 42-43).

Tuna vilâyetinin nüfusu yaklaşık 2,5 milyon kadardır. Hrıstiyan halk vilayetin toplam nüfusunun hemen hemen \% 60'ını Müslüman halk ise yaklaşık \%40'nı oluşturmaktadır. Tuna Vilayetinde genel ortalama 100 haneden fazla haneye sahip köylerin sayısı en çoktur. Nüfusu karışık olan ve tamamen Müslümanlardan oluşan köyler, Hrıstiyan köylerden daha büyüktür. Köy hanesinin yapısı \% 60'tan fazla olmakla nüfusun nükleer modelinin üstün geldiğini göstermektedir. Sıradan basit bir aile bir hanedir ve bu anne baba ve çocuklardan meydana gelmektedir. Anne, baba, çocuklar ve torunlardan oluşan geniş ailelere gelince genelde Hrıstiyanlara özgü tipi ve oranı yaklaşık \% 25'tir. Tuna vilayetinin progresif yaş yapısına sahip olduğu görülmektedir ve bu yap1 Hrıstiyanlarda daha yüksektir. Köy nüfusunun mesleksel yapısı yan gelirler açısından epey büyük bir çeşitlilik göstermektedir (Draganova, 2006: 31). 
Tuna vilayetinin 1864 yılında etnik ve dini yapısı büyük bir çeşitlilik göstermektedir. Ortodoks Hristiyan Bulgarlar ve Sünni Müslüman Türkler, nüfusun ana etnik ve dini bileşenlerini oluşturmuştur. Ayrıca vilayetin nüfusunda Kırım ve Kafkaslar'da Rusya'ya kaybedilen topraklardan gelen Çerkez ve Tatar muhacirler, Müslüman ve Hrıstiyan Çingeneler, Sefarad Yahudileri, Ortadoks Eflaklılar, Yunanlılar ve Gregoryen Ermeniler de bulunmaktadır. $\mathrm{Bu}$ gruplara ek olarak Pomaklar (Bulgarca konuşan, Müslümanlar), Gagavuzlar (Türkçe konuşan, Hrıstiyanlar), Bulgar Rum Katolikler, Şii Müslümanlar (Alevi ve Bektaşi Müslümanlar), eski Ruslar, Ukraynalı Kazklar, Aşkenaz Yahudiler ve Protestan Ermeniler gibi küçük toplumlar da yer almaktadır. Vilâyetin 26 idari biriminde Hrıstiyan Bulgarlar, nüfusun yüzde 60-80 oranında çoğunluğunu sağlamıştır. Fakat bu Müslümanlar ve Gayrimüslümler arasında olan doğal sınır olan Yantara nehrinin doğusunda yaşayan Müslüman nüfus için yüzde 70 'den ibarettir. Bazı kasabaların nüfusu ise tamamen Müslümanlardan oluşmaktadır. Kalan nüfusun doğudaki kısmını ise Bulgarlar, Ermeniler, Yunanlılar ve Yahudiler oluşturmaktadır (Çelik, 2010: 43). Tuna gazetesine göre 1873'te vilâyetin nüfusu kadınlarla birlikte 2.100 .000 'in üzerindedir. Vilâyet genelinde Müslüman nüfus oran1 \%43,17'ye yükselirken, Gayrimüslüm nüfus oran1 ise $\% 56,83$ 'e gerilemiștir. Vilâyet genelinde hane başı nüfus ortalaması, Müslümanlarda 5,63, Gayrimüslümlerde 6,92 olup, genel ortalama 6,25'tir (Koyuncu, 2014: 710).

\section{Sonuc}

Arkeolojik kalıntılar, Proto - Bulgar dil kalıntıları ve İdil Bulgarlarına ait mezar taşlarındaki kitabeler, Bulgarlar'ın Türk kökenli bir kavim olduğunun delilleridir. Bulgarların, hangi Türk kavmine mensup oldukları ve tarih sahnesine ne zaman çıktıkları, Azak Denizi çevresine ne zaman geldikleri tam olarak bilinmemektedir.

Bulgarlar, Göktürk Devleti'nin idaresi altında uzun bir süre kaldıktan sonra, 630 yılında, Göktürk Devleti'nin güçsüzleşmesi üzerine, “Büyük Bulgarya Devletini” kurmuşlardır. Bu Devlet, 665'den sonra komşu Hazar Devleti, tarafından parçalanmıştır.

Asparuh idaresindeki Bulgarlar, Tuna’ya doğru yönelmişler ve Balkanlar'a girerek (668-671), Tuna Bulgarları Devleti'ni kurmuştur. Oğuzlar ve Hunlarla karışarak, Bulgar adı altında Balkanlarda hakimiyet kurmuşlardır. Bulgarların ve Avarların, Bizans'la mücadeleleri, Slav kabilelerinin Balkanlara yavaş yavaş yerleşmesine ortam hazırlamıştır. Balkan Yarımadası, V. yüzyıl sonlarından itibaren hızla Slavlaşmaya başlamıştır. Karadeniz kuzeyinde, Büyük Bulgarya Hanlığı'nın parçalanmasından sonra, Bulgarlardan bir kısmı batıya ilerleyerek (645) Bizans'la yüzy1llı mücadeleyi devam ettirmişlerdir. 680-681 tarihlerinde Balkanlara, yerleşmiş yepyeni bir devlet kurmuşlardır. Bugünkü İslav Bulgarlar, tarihlerini bu devletle başlatmışlardır. VIII. yüzyılda Slavların Bulgar aristokrasisi arasına kabul olunması, bu Türk Devletinin Slavlaşmasına doğru büyük bir adım oldu. Hrıstiyanlığın kabul olunması (865) ile beraber Türk Bulgarlar tamamiyle eriyip gitmiştir. Resmi dil Slavlaşmış, Türkçe unvanlar atılmıştır. Bulgaristan üzerinde artan Hrıstiyanlık baskısı Bulgar Türklerinin hızlı bir şekilde Slavlaşmasını sağlamıştır. Bu sıralarda da Karadeniz kuzeyinde bir çok Türk kavimleri Balkanlar'a gelip yerleşmişlerdir. Bunlardan Kumanlar, bağımsız bir Bulgar Devleti'nin yeniden kurulmasına ön ayak olmuşlardır. Bundan sonra Bulgar Devleti bir müddet Altın Ordu Kıpçakların himayesinde kalmıştır.

Büyük Kosova Savaşı'ndan sonra (1839), Tuna ve Vidin'e kadar bütün Bulgaristan Osmanlı hakimiyetine girmiş ve Rumeli Beylerbeyliği'ne bağlanmıştır. Osmanlı Devleti, yerli Hrıstiyan halk dini ve milli değerlerini yaşamada serbest bırakılmıştır. Osmanlı, Tanzimat'ın ilanından sonra, Bulgar köylüsünün toprak sahibi olması zorunluluğunu, fark ettiği sırada Bulgarlarda, bağımsızlık hareketi başlamıştır. Osmanlı hakimiyetinde Bulgarların, XVIII. yüzyıla kadar kayda değer bir isyan hareketi olmamıştır. Bulgarların milliyetçilik faaliyetleri 
ilk defa XVIII. yüzyılın ikinci yarısında başlamış, asıl dönüm noktası ise 1828/29 OsmanlıRus savaşında gerçekleşmiştir.

Bulgarlar, Ruslar için Panislavizm politikasının en önemli vasıtası niteliğindedir. Ruslar, Bulgarların çete faaliyetlerine destek vermiş, Panslavist fikirlerine hizmet edecek gençler yetiştirmek amacı ile modern Bulgar okulları açılması desteklenmiştir. Bulgarları Rumlaştıran ruhban sınıfı, Bulgar dili ve kültürel geleneklerini baskı altında tutmak ve Osmanlı dönemi boyunca Bulgarları karakterize eden tarihsel bir hafiza kaybına yol açmakla suçlanmıştır. Patrikhanenin Rumlaştırma politikasına maruz kalan tek millet Bulgarlar değildir. Bulgarlar başta olmak üzere diğer bütün Ortodokslar bu durumdan etkilenmiş, dillerini ve kültürlerini baskı altına alan milliyetçi politikalara karşı mücadele etmişlerdir. Bulgarlar, Rusların Balkanlara doğru hareketinden, faydalanarak bağımsızlık faaliyetleri göstermeye başlamışlardır. XVIII. yüzyılın sonlarından itibaren Bulgar coğrafyasında yoğun faaliyetlerde bulunan Rusya, 1841 yılında Niş'te çıkan olaylardan yararlanarak, Niş halkının Türk yönetiminde memnun olmadığını ve yapılanları yerinde görmek için bir memur görevlendirmek istediğini bildirmiştir. Osmanlı Devleti önce bu isteğin asilleri cesaretlendireceğini düşünse de Rusya'nın bu isteğini kabul etmek zorunda kalmıştır. Gülhane Hatt1 Hümâyununda, Osmanlı tebaasının haklar yönünden eşit olduğu belirtilmiştir. Vidin, Niş ve Tırnova gibi önemli yerlerde Bulgar milli ayaklanmalar sonrası Bulgar milli hareketi hem ideolojik gelişme hemde organizasyon olarak 1860'larda doruk noktasına ulaşmıştır. 1862’de merkezi Bükreş’te olan Bulgar İhtilal komitesi kurulmuştur.

Mithad Paşa Tuna Vilayeti'nin güvenliği ve refahı için etkili çalışmalar yapmış, önemli başarılar elde etmiştir. Tuna vilâyetindeki dört y1llık valiliği boyunca Mithad Paşa ayrılıkçı hareketlere ve ve Rusya'nın Panslavist politikalarına karşı başarılı bir şekilde mücadele göstermiştir. Bunda başka "Osmanlılık" ideolojisi altında, gayrimüslüm nüfusu ve Müslümanlarla birleştirmeye yönelik birçok reformlar gerçekleştirmiştir. Mithad Paşa görevinin bitmesinden sonra hükümete verdiği raporda, Bulgaristan'da milliyetçilik hareketlerine dikkat çekmiş, askerlik ve eğitim alanlarında alınması gerekli önlemlerin altını çizmiştir. Fakat bunlar idrak edilmediği için Bulgaristan meselesi, devam etmiştir.

Bulgar Ortodoks Kilisesinin 11 Mart 1870 tarihindeki bir fermanla tanınması sonrasında müstakil ve milli Bulgar kilisesi kurulmuştur. Bu kuruluş ile Bulgarlar Rum patrikhanesinin nüfuzundan ve Rum papazlarının istismarından kurtulmuşlardır. Dini bağımsızlıklarını kazanan Bulgarlar, siyasi bağımsızlıklarını kazanmak için savaşmaya, 1875 ve 1876 yılında yapılan iki güçlü ihtilal teşebbüsüyle devam etmiştir. Balkanlar'da Osmanlı Devletinin feci yenilgisiyle sonuçlanan 1877-1878 Osmanlı - Rus savaşı bir dönüm noktası olmuştur. Temmuz 1876 tarihinde, Osmanlı Devleti'nin paylaşılmasını tasarlayan Rusya ve Avusturya 2 Aralık'ta başlayacak olan Avrupa Konferansı'nın İstanbul'da toplanmasını önermiştir. Avrupa güçleri Osmanlı Devleti'nin konferansta alınan kararları içeren bir ültimataom vermiştir. Bulgaristan, doğu ve batı olarak ikiye bölünürek otonomi kazanacak ve Hrıstiyan valiler tarafından yönetilecektir. Ayrıca direkt olarak Bulgaristan'daki reformları ve yeni idareyi denetlemek üzere Avrupa güçlerinin temsilcilerinden oluşan bir komisyon Bulgaristan'da kurulacaktır. Osmanlı hükümeti tarafından bu kesin uyarıya verilecek yanıt, Mithad Paşa tarafindan belirlenmiş ve parlemontaya sunulmuştur. Mithad Paşa konferansta alınan kararların Osmanlı Yönetimi için kabul edilemez olduğuna işaret etmiştir. Avrupa güçlerinin temsilcileri manalı bir şekilde İstanbul'u terk etmiştir.

Bulgarların siyasi bağımsızlıklarını elde etme faaliyetlerinde, milli kimlikleri değil, daha çok dini kimlikleri belirleyici olmuştur. Osmanlı nüfus ve vergi sicilleri, XVI. yüzyılda Müslüman Türklerin bu bölgelerde nüfusun büyük bir parçasını oluşturduğunu belirtmektedir. Tuna vilâyetinin nüfusu yaklaşık 2,5 milyon kadar olup, Hrıstiyan halk vilayetin toplam nüfusunun hemen hemen \% 60'ını, Müslüman halk ise yaklaşık \%40'nı oluşturmaktadır. 


\section{Kaynakça}

Armaoğlu, F. (2003). 19. Yüzyll siyasi tarihi (1789-1914), TTK, Ankara.

Aydın, M. (2005). Balkanlar'da isyan, Yeditepe Yayınevi, İstanbul.

Çelik, M. (2010). Balkanlar'da Tanzimat: Midhad Paşa'nın Tuna vilâyeti valiliği (18641868), Libra Kitapçılık ve Yayıncılık, Ankara.

Draganova, S. (2006). Tuna vilayetinin köy nüfusu, Türk Tarih Kurumu Yayınları, Ankara.

Gençoğlu, M. (2011). " 1864 ve 1871 Vilâyet Nizamnamelerine göre Osmanlı taşra idaresinde yeniden yapılanma’, Çankırı Sosyal Bilimler Enstitüsü Dergisi, S.II, Ankara, s.s. 3234

İnalc1k, H. (1993). “Türkler (Osmanlılar)', Türk Diyanet Vakfı İslam Ansiklopedisi, XII/2, İstanbul s.s.292.

İnalcık, H. (1964). “'Tanzimatın uygulanması ve sosyal tepkiler”, Belleten, C.28, s.1-642

İnalcık, H. (1943). Tanzimat ve Bulgar meselesi, T.T.K. Basımevi, Ankara.

Kafesoğlu, İ. (1983). "Tuna Bulgarlarının tarih ve kültürüne kısa bir bakış", Güney-Doğu Avrupa Araştırmaları Dergisi, 1-92

Karal, E.Z. Büyük Osmanlı tarihi. T.T.K. Yayınları, C.3, Ankara.

Kılıç, S. (2005). “1864 Vilayet Nizamnamesi'nin Tuna vilayetinde uygulanması ve Midhad Paşa', Ankara Üniversitesi Dil-ve Tarih-Coğrafya Fakültesi Tarih Bölümü Tarih Araştırmaları Dergisi, C.24, S.37, Ankara.

Koyuncu, A. (2014). "Tuna vilayetinde nüfus ve demokrasi (1864-1877)", Turkish Studies International Oeriodical Fort he Languages, Literature and History of Turkish or Turkic, Volume 9/4 Spring

Köse, O. (2006). ' 'Bulgaristan emareti ve Türkler (1878-1908)', Türkoloji Dergisi 1, S.2., 240-241

Kurat, A. N. (1993). “Bulgaristan”. Türk Diyanet Vakfi İslam Ansiklopedisi, C.2, İstanbul

Kurat, A. N. (2002). IV-XVIII. Yüzylllarda Karadeniz’in kuzeyindeki Türk kavimleri ve devletleri, Murat Kitabevi Yayınları, Ankara.

Merçil, E. (2006). Müslüman - Türk devletleri tarihi, T.T.K. Ankara.

Özgüldür, Y. Özgüldür, S. (1994). “'1876 Anayasası'nın hazırlanmasında Midhad Paşa'nın rolü ve fonksiyonu', dergiler.ankara.edu.tr. (13.12.2014)

Şentürk, M. H. (1992). Osmanlı devleti'nde Bulgar meselesi (1850-1875), Ankara.

Şimşir, B. (1989). Rumeli'de Türk göçleri, C.II. TTK, Ankara.

Toprak, S. (2013). “'Bulgaristan'ın bağımsızlığında Rusya'nın rolü' . History Studies Special Issue on Balkan Wars, Volume 5/Issue 6

Tuğlacı, P. (1984). Bulgaristan ve Türk - Bulgar ilişkileri, Cem Yayınları, İstanbul.

Uzunçarşı1l, İ.H. (1987). Osmanlı tarihi, C.I, Ankara.

Uzun, A. (2002). Tanzimat ve sosyal direnişler, Eren Yayınları, İstanbul. 